\title{
Patients' Opinions About PET/CT Scans, Evaluated Before and After Oncological Imaging
}

\author{
PET/BT Görüntüleme Öncesi ve Sonrasında Onkoloji Hastalarının \\ PET BT Çekimi ile İlgili Kanaatleri
}

\author{
Ilce Huri Tilla ${ }^{1}$, Elhan Vargol Sezen ${ }^{2}$, Halis Hatice ${ }^{3}$, Yazici Esra ${ }^{4}$ \\ ${ }^{1}$ Sakarya University Faculty of Medicine Department of Nuclear Medicine, Sakarya Turkey \\ ${ }^{4}$ Psychiatrist, Sakarya University Faculty of Medicine Department of Psychiatry, Sakarya Turkey \\ Yazışma Adresi / Correspondence: \\ Huri Tilla İlce \\ Sakarya University Faculty of Medicine Department of Nuclear Medicine, Sakarya Turkey \\ T: +905336214910 E-mail : hilce@sakarya.edu.tr \\ Geliş Tarihi / Received : 06.05.2021 Kabul Tarihi/ Accepte: 07.12.2021 \\ Orcid : \\ Huri Tilla Ilce https://orcid.org/0000-0002-8672-707x \\ Sezen Elhan Vargol https://orcid.org/0000-0001-5731-5992 \\ Hatice Halis: https://orcid.org/0000-0002-9938-1856 \\ Esra Yazici https://orcid.org/0000-0002-2575-7398 \\ ( Sakarya Tip Dergisi / Sakarya Med J 2021, 11(4):879-888 ) DOI: 10.31832/smj.929085
} 2 Sakarya University Faculty of Medicine Training and Research Hospital Department of Nuclear Medicine, Sakarya Turkey ${ }^{3}$ Sakarya University Faculty of Medicine Training and Research Hospital Department of Radiation Oncology, Sakarya Turkey

\begin{abstract}
Objective Positron emission tomography/computed tomography (PET/CT) imaging is used for many purposes such as diagnosis and staging of cancer patients and there may be different worries and opinions about this method. It is known patients may be anxious before PET/CT scan, but it is not well known whether their opinions continue after scanning. The aim of this study was to evaluate pre- and post-imaging worries and opinions of oncological patients referred to the Nuclear Medicine Clinic for PET/CT imaging.

Materials Sociodemographic data form, STAI-I state, STAI-II trait anxiety forms, pre-test and post-test forms evaluating confidence-knowledge-worry about PET/CT procedure and Methods which is prepared by study team were applied to cancer patients referred to Nuclear Medicine Clinic.

Results Confidence and worry were associated with gender, living place, well informed and being knowledgeable about the illness $(\mathbf{p}<0.05)$. In pre-test, it is observed that men relied PET/CT imaging more than women. However, there was no significant difference in post-test confidence scores. Before scanning, women were more worried than men. The worry scores of the patients living in rural areas both before PET/CT and after PET/CT procedure were higher than those living in urban areas and it was inversely correlated with knowledge and confidence

Conclusion PET/CT procedure can be an alarming experience for patients. In this process, well informed and being knowledgeable is associated with lower worry and higher confidence. Making this process more reassuring can contribute to decreased worry.

Keywords PET/CT; Cancer; Confidence; Worry
\end{abstract}

Öz

Amac Pozitron emisyon tomografi/bilgisayarl tomografi (PET/BT) görüntüleme kanser hastalarının tanı ve evrelemesi gibi birçok amaçla kullamılmakta olup, bu tetkik ile ilgili farkh kaygı ve kanaatler olabilmektedir. Hastaların PET/BT çekimi öncesi kaygll olabildikleri bilinmektedir ancak çekim sonrasında görüslerinin devam edip etmediği ivi bilinmemektedir. Bu çalșmanın amaci PET/BT görüntüleme için Nükleer Tip Kliniğine yönlendirilen onkolojik hastalarda görüntüleme öncesi ve sonrası çekimle ilgili kaygı ve görüşlerinin değerlendirilmesidir.

Gereç ve Bu calısmada Nükleer Tip Kliniğine basvuran kanser hastalarnna sosyodemografik veri formu, State Trate Anxiety Inventory I (STAI-I) durumluluk ve State Trate Anxiety Inventory II Yöntemler (STAI-II) süreklilik formları ile çalışma ekibi tarafindan oluşturulan PET/BT öncesi ve sonrası, ön test ve son test ile PET/BT prosedürüne dair güven-bilgi ve endişe formları uygulandı.

Bulgular Bu çalı̧̧mada güven ve endişe; cinsiyet, yașanılan yer ve hastalik konusunda bilgilendirilmiș ve bilgili olmak ile ilişkili bulunmuștur (p<0.05). Ön testte erkeklerin yapılacak görüntülemeye, kadınlardan daha fazla güvendiği saptanırken, son test güven puanlarında erkekler ve kadınlar arasında anlamlı bir fark saptanmadı. Kadınlar PET-BT çekimi öncesi erkeklere göre dahe kayglliydı. Kirsal kesimde yaşayan hastaların hem PET/BT öncesi, hem de PET/BT sonrası işlemle ilgili kaygı puanları kentsel kesimde yaşayanlara göre daha yüksek bulundu. Hastaların PET/BT çekimi strasında duyulan endișeleri; bilgi ve güven ile ters korelasyon gösteriyordu.

Sonuç PET/BT çekimi hastalar için endişe verici bir deneyim olabilmektedir. Bu süreçte hastaların bilgilendirilmesi daha düşük endişe ve daha yüksek güven skorları ile ilişkilidir. Bu sürecin daha güven verici bir hale getirilmesi, bu endişenin azalmastna katkı să̆layabilir. 


\section{INTRODUCTION}

Molecular imaging methods have taken an important place in the last decade, especially in the diagnosis and follow-up of cancer patients. Positron emission tomography/ computed tomography (PET/CT) with 2-[18F] Fluoro-2deoxy-D-glucose (FDG) is a minimally invasive method for cancer patients and PET/CT is a sensitive, useful imaging method in the diagnosis, staging, restaging and prognostic evaluation of cancer. ${ }^{1}$

Exposure to potentially frightening and unfamiliar technology causes anxiety, especially in claustrophobic patients. ${ }^{2}$ In addition, PET/CT imaging can be perceived as an examination that causes fear and anxiety as it can confirm the presence of cancer or change the therapeutic approach. ${ }^{3}$

Anxiety (a clinical definition that is regardless of the cause of certain or uncertain stimuli independently) is the feeling of fear that occurs when faced with threatening or stressful situations, arising from the inner conflicts of the person. ${ }^{4}$ Anxiety is a common condition that can sometimes be strong enough to interfere with daily activities. ${ }^{5}$ Worry, on the other hand, defines the clarified emotion towards a certain process, and worry may appear as a parameter independent of the person's anxiety. Anxieties and thoughts are concepts that affect and trigger each other. ${ }^{6}$

In a previous study, anxiety was evaluated before and after PET/CT scanning and no statistically significant difference was found in terms of sociodemographic characteristics and anxiety levels. Anxiety is likely not only before but also after a scan and the main factor that leads to this emotional response is the worry concerning the screening results. ${ }^{7}$ PET/CT imaging performed for staging purposes and/or to evaluate tumor recurrence has been shown to be a significant source of anxiety. ${ }^{8}$ While no significant difference in anxiety levels have been reported between genders before PET/CT scans, males have been observed as having significantly higher anxiety levels after scans. ${ }^{3}$
Although there are studies that attempt to correlate PET/ CT scans with anxiety levels, studies on how patients evaluate the PET/CT process in terms of thoughts and opinions other than psychiatric symptoms are limited. Developing technology and access to information may have changed the existing opinions over the years. Therefore, evaluating current worries and thoughts about PET/CT in the general population is valuable in ensuring the correct focus when communicating with patients. In addition, while the initial opinion of the patients is different when they do not encounter PET/CT scan, it is not known whether these views continue after imaging.

Comprehensive information is given to the patients prior to PET/CT scanning. When planning the appointment, a brief and simple explanation of the procedure should be made, including information about fasting time, oral contrast preparation and the need to stay away from exercise. On the day of imaging, this minimally invasive procedure should be performed as comfortably as possible for image quality and diagnostic accuracy. However, high anxiety affects the normal biodistribution of FDG by changing the physiological parameters of the patient (such as causing abnormal distribution in the muscles or brown adipose tissue) that can decrease the imaging quality. ${ }^{3,9}$ Consequently, an appreciation of the anxiety levels of individuals before PET/CT scans can be a helpful tool for the healthy progression of imaging.

However, there are very few published data on anxiety experience among patients, especially regarding imaging studies, ${ }^{8}$ and studies on the relationship between patients' anxiety and thought content in the setting of PET/CT are limited.

The aim of this study is to evaluate the levels of worry and anxiety before and after PET/CT scanning in cancer patients referred to the Nuclear Medicine Clinic, to address their opinions regarding PET/CT imaging and to correlate their anxiety levels with sociodemographic characteristics 
and levels of information.

\section{MATERIALS and METHODS}

To evaluate the changes in thoughts and basal anxiety levels of cancer patients before and after PET/CT imaging, patients who volunteered to participate in the study were asked to fill out questionnaires under observation following their verbal consent. Patients with an organic or mental illness were excluded in the study. This study was designed in accordance with the Declaration of Helsinki Principles and received approval from the Sakarya University Faculty of Medicine Ethics Committee on 11 October 2017. (Ethics no: 16214662/050.01.04/68). 150 consecutive volunteer patients who applied for PET/CT imaging from October 2017 to December 2017 and met the inclusion criteria were included in the study, although 150 patients participated in the study, not all patients who filled out a form before PET/CT filled in the second form after PET/ CT. Therefore, evaluation was made on 110 patients who filled out both forms. The scores are given by valid percent to avoid confusion.

PET/CT Imaging Protocol: After a 6-hour fasting period, patients were injected intravenously with 296-370 MBq of FDG. Imaging was initiated after an uptake period, during which patients were encouraged to rest in a long armchair. The average waiting time was around 60 minutes and the acquisition time ranged from 18 to 25 minutes. PET/CT images were acquired using Siemens mCT 20 excel LSO PET/CT scanner (Siemens Molecular Imaging, Hoffmann Estates, Illinois, USA).

\section{Materials}

Sociodemographic and Clinical Data Form: A form was prepared by the research team to obtain sociodemographic information including age, gender, educational level, marital status, psychiatric treatment history and drug use.

Patient Information Form regarding PET/CT Scanning: Two forms, consisting of 15 questions each, was based on the information known to the patients about PET/CT imaging and the general prejudices known in the society, to evaluate their confidence and worries about the procedure. The first form (the pre-test) was administered one hour before scanning and the second form (the post-test) was administered immediately after scanning. Both forms included identical questions about the procedure. The questions evaluated the sub-dimensions of confidence and worry on the transaction.

Evaluations in the form were made in two sub-calculation categories.

1. In order to evaluate the internal consistency of the form before and after the imaging, Cronbach's alpha analysis was performed by taking into account the 5-point Likert pattern of the form, and the Cronbach's alpha value was calculated as 0.725 for the confidence sub-dimension before the imaging and 0.718 for the anxiety sub-dimension. After imaging, the Cronbach alpha value for the confidence sub-dimension was 0.732; for worry, the Cronbach alpha value was 0.703 , and it was found to have an acceptable internal consistency. Sub-titles were added together and subjected to scale analysis, and since the scope of the items was different from each other, total scoring was not made. Total scores of questions about confidence-knowledge and questions about worry were calculated.

2. In the second stage, the form was transformed into a triple categorical form in order to capture the thought transformations such as "I agree, I am not sure, I disagree". The pre-test and post-test items were compared item by item using Wilcoxon Signs Ranking test.

Spielberger State-Trait Anxiety Inventory (STAI-I-II): In this study, the aim was to evaluate the momentary anxiety of the patients before PET/CT and the previous continual worries STAI form. The form (used in the patients' native language as proposed by Öner and Le Compte) consists of two parts: the state anxiety scale (STAI form TX-1) and the trait anxiety scale (STAI form TX-2), each with 20 questions. STAI form TX1 shows how the individual feels at 
a certain time and under certain conditions, while STAI form TX-2 is a scale that determines how the individual feels regardless of the situation and circumstances. ${ }^{10}$ The adaptation of the scale to Turkish was done by Öner and Le Compte. ${ }^{11}$ According to the limit values in STAI form TX$1 / 2$, the anxiety state of the patient was interpreted as: no anxiety (0-19 points), mild anxiety (20-39 points), moderate anxiety (40-59 points), severe anxiety (60-79 points) or panic as a severe crisis ( 80 and above).

Practice: The patients who applied to the Nuclear Medicine Department were taken to a quiet resting room and a preliminary interview was made about the study. The sociodemographic data form, the patient information form (before the PET/CT procedure) and the State-Trait Anxiety Inventory were applied to the patients who accepted to participate in the study. Thereafter, PET/CT imaging was performed. After the procedure, evaluation was made with a $\mathrm{PET} / \mathrm{CT}$ post-imaging patient information form.

Statistical analysis: The data was analyzed in the statistical software SPSS, version 21.0. The mean score differences between the groups were compared using Student's t test for variables that fit the normal distribution, and the Mann Whitney-U test for those that did not fit the normal distribution. For correlation analysis, Pearson's correlation analysis was used in case of normal distribution. In addition, Cronbach Alpha and Wilcoxon Signs Ranking tests were performed (as explained in the section related to the form). The statistical significance level was set as 0,05 . This study was approved of the Ethic Committee of Sakarya University and informed consent was obtained from all enrolled patients.

\section{RESULTS}

\section{Sociodemographic Features}

110 patients undergoing cancer treatment participated in this study; 53 were women and 57 were men. Sociodemographic and clinical data of the patients are summarized in Table 1.
Patients' level of anxiety, confidence and state-continuity anxiety about PET/CT procedure before PET/CT scan

\begin{tabular}{|c|c|c|}
\hline \multicolumn{3}{|c|}{$\begin{array}{l}\text { Table 1: Sociodemographic Features and } \\
\text { patients. }\end{array}$} \\
\hline \multicolumn{3}{|c|}{ Sociodemographic Features } \\
\hline Age (year) & \multicolumn{2}{|c|}{ Mean: $55.74 \pm 13.05(18-84)$} \\
\hline Gender & Men $51.8 \%$ & Women $48.2 \%$ \\
\hline Marital status & Single: $15 \%$ & Married: $85 \%$ \\
\hline Job status & Working: $49 \%$ & Not working: $51 \%$ \\
\hline $\begin{array}{l}\text { Duration of } \\
\text { education (year) }\end{array}$ & \multicolumn{2}{|c|}{ Mean: $5.88 \pm 2.31(5-14)$} \\
\hline \multirow{4}{*}{ Education levels } & $\begin{array}{c}\text { Primary school } \\
\text { or lower }\end{array}$ & $58.2 \%$ \\
\hline & Middle school & $21.8 \%$ \\
\hline & High school & $15.5 \%$ \\
\hline & University & $4.5 \%$ \\
\hline $\begin{array}{l}\text { Place of birth } \\
\text { (Indigenousness) }\end{array}$ & Sakarya: $57.6 \%$ & Others: $42.4 \%$ \\
\hline Living place & Rural 28\% & Urban $72 \%$ \\
\hline \multicolumn{3}{|c|}{ Information on the reason of PET/CT imaging of patients } \\
\hline $\begin{array}{l}\text { Duration of illness } \\
\text { (Month) }\end{array}$ & \multicolumn{2}{|c|}{ Mean: $23.81 \pm 28.18(0.5-204)$} \\
\hline \multirow{4}{*}{$\mathrm{PET} / \mathrm{CT}$ reason } & \multicolumn{2}{|c|}{ Diagnosis: $4.5 \%$} \\
\hline & \multicolumn{2}{|c|}{ Staging: $26.4 \%$} \\
\hline & \multicolumn{2}{|c|}{ Treatment response assessment: $41.8 \%$} \\
\hline & \multicolumn{2}{|c|}{ Others: $1.1 \%$} \\
\hline \multicolumn{3}{|c|}{ Cancer Diagnosis Distribution (\%) } \\
\hline Head and Neck & \multicolumn{2}{|c|}{5.7} \\
\hline Lung & \multicolumn{2}{|c|}{16.0} \\
\hline Breast & \multicolumn{2}{|c|}{19.8} \\
\hline Gastrointestinal & \multicolumn{2}{|c|}{18.9} \\
\hline Haematological & \multicolumn{2}{|c|}{15.1} \\
\hline Genitourinary & \multicolumn{2}{|c|}{14.2} \\
\hline Musculoskeletal & \multicolumn{2}{|c|}{0.9} \\
\hline Others & \multicolumn{2}{|c|}{9.4} \\
\hline Total & \multicolumn{2}{|c|}{100.0} \\
\hline \multicolumn{3}{|c|}{ Information on Psychiatric Treatment (\%) } \\
\hline $\begin{array}{l}\text { Patient with a previous } \\
\text { psychiatric diagnosis }\end{array}$ & \multicolumn{2}{|c|}{26.4} \\
\hline $\begin{array}{l}\text { Patients with a current } \\
\text { psychiatric diagnosis }\end{array}$ & \multicolumn{2}{|c|}{12.8} \\
\hline $\begin{array}{l}\text { Using psychiatric } \\
\text { medication }\end{array}$ & \multicolumn{2}{|c|}{11.8} \\
\hline
\end{tabular}




\section{Gender}

In this study, no significant difference was found in the total scores of the worries and confidence questions related to the PET/CT procedure when the answers before and after the procedure were compared. However, when the relationship of these scores with gender is evaluated; In the pre-test, men relied more on imaging than women did. While there is no significant difference between the post-test confidence scores between men and women; It was observed that women had higher worry scores in both pre-test and post-test (Table 2).
$21.33 \pm 3.80 \mathrm{p}<0.05)$

The confidence scores of those who said yes to the item "I have been informed sufficiently about my illness" were higher than those who said no during the pre-test (Mann Whitney $\mathrm{U}$, respectively $29.38 \pm 4.38 ; 27.48 \pm 7.78 \mathrm{p}=$ 0.034).

\section{Relationship with State and Continuity Anxiety}

When the correlation analysis was conducted; positive correlation was found between pre-test confidence total score and post-test confidence total score, negative correlation was found between pre-test worry and post-test

\begin{tabular}{|l|c|c|c|c|}
\hline \multicolumn{2}{|l|}{ Table 2: Male-female comparison of confidence, worries-anxiety levels before and after PET/CT and total scores } \\
\hline & Men & Women & All patient & $\mathrm{p}$ \\
\hline STAI-I State Total score & $41.84 \pm 5.78$ & $40.67 \pm 5.95$ & $41.24 \pm 5.86$ & 0.383 \\
\hline STAI-II Continuity Total Score & $45.53 \pm 5.83$ & $49.30 \pm 5.25$ & $47.44 \pm 5,83$ & 0.004 \\
\hline Confidence and knowledge pre-test ${ }^{*}$ & $29.60 \pm 5.54$ & $28.09 \pm 3.52$ & $28.84 \pm 4.67$ & 0.010 \\
\hline Confidence and knowledge post-test & $29.91 \pm 5.23$ & $28.75 \pm 2.93$ & $29.41 \pm 4.40$ & 0.293 \\
\hline Worry about PET/CT pre-test & $18.92 \pm 4.84$ & $21.06 \pm 3.66$ & $19.97 \pm 4.42$ & 0.015 \\
\hline Worry about PET/CT post-test & $18.45 \pm 4.61$ & $20.57 \pm 3.36$ & $19.48 \pm 4.16$ & 0.031 \\
\hline *: Since the data are not normally distributed, they were calculated with Mann Whitney U. Student's t test was used as other data are normally distributed. \\
\hline
\end{tabular}

There was no significant relationship between education level, marital status, disease diagnosis, psychiatric treatment history and duration of medical illness, with confidence and worry before and after PET/CT.

Before and after PET/CT scan, there was no significant relationship between birthplace and confidence-worry; when the place of residence was evaluated, the worry scores of the patients living in rural areas before the PET/ $\mathrm{CT}$ procedure both and after the PET/CT about procedure were higher than those living in the urban areas (respectively for the worry Pre-test: rural score $=21.80 \pm 4.36$; urban score $19.58 \pm 4.31$; for the worry Post-test: rural score $=21.66 \pm 3.89$; urban score $18.97 \pm 3.88$ ).

\section{Knowledge on the disease}

The pre-PET/CT test worry scores of those who said yes to the question "I am knowledgeable about the disease" were lower than those who said no (respectively $19.12 \pm 4.63$; worry, negative correlation was found between post-test confidence and pre-test worry and there was a positive correlation between pre-test worry and post-test worry and STAI II (Table 3).

\section{Patients' Responses of Pre and Post PET / CT}

Pre- and post-PET/CT responses were evaluated in two ways:

1. For Knowledge-Confidence subscale and Worry scale scores, out of total score according to Likert scoring; Student's $t$ test and Mann-Whitney U test were used for pre-test and post-test mean score comparisons. No significant differences were detected ( $\mathrm{p}>0.005)$.

2. For categorical evaluation of pre- and post-PET/CT values, responses were classified as "agree", "undecided" and "disagree". According to the Wilcoxon test, the difference was not statistically significant. The distribution of responses by items are shown in Table 4. 
Sakarya Med J 2021;11(4):879-888

İLÇE et al., : Oncologıcal Patıents' Opınıns Before And After Pet/Ct Scans

\begin{tabular}{|c|c|c|c|c|c|}
\hline & & $\begin{array}{c}\text { Post-test Confidence } \\
\text { Total }\end{array}$ & Pre-test worry total & Post-test worry total & STAI- II Total \\
\hline \multirow{2}{*}{$\begin{array}{l}\text { Pre-test Confidence } \\
\text { Total }\end{array}$} & Correlation & .786 & -.279 & -.238 & -.053 \\
\hline & $\mathrm{p}$ & .000 & .006 & .047 & .651 \\
\hline \multirow{2}{*}{$\begin{array}{l}\text { Post-test Confidence } \\
\text { Total }\end{array}$} & Pearson Correlation & 1 & -.287 & -.218 & .125 \\
\hline & Sig. (2-tailed) & & .025 & .083 & .357 \\
\hline \multirow{2}{*}{ Pre-test worry Total } & Pearson Correlation & -.287 & 1 & .817 & .398 \\
\hline & Sig. (2-tailed) & .025 & & .000 & .000 \\
\hline \multirow{2}{*}{ Post-test worry Total } & Pearson Correlation & -.218 & .817 & 1 & .311 \\
\hline & Sig. (2-tailed) & .083 & .000 & & .015 \\
\hline
\end{tabular}

Table 4: Categorical assessment of pre and post PET/CT values:

\begin{tabular}{|c|c|c|c|c|}
\hline & Agree \% & $\begin{array}{c}\text { Unsure } \\
\%\end{array}$ & $\begin{array}{c}\text { Disagree } \\
\%\end{array}$ & \\
\hline \multirow{2}{*}{$1^{\star}$. PET/CT imaging is ordered by the doctor because it is really necessary. } & 87.3 & 4.5 & 8.2 & Pre-test \\
\hline & 90.7 & 4.7 & 4.7 & Post-test \\
\hline \multirow{2}{*}{$2^{\star}$. The benefit I will obtain from PET/CT imaging exceeds the radiation risk I am exposed to. } & 50 & 38 & 12 & Pre-test \\
\hline & 41.5 & 45.1 & 13.4 & Post-test \\
\hline \multirow{2}{*}{$3^{*}$. PET/CT scan increases my risk of getting cancer. } & 11.2 & 47.7 & 41.1 & Pre-test \\
\hline & 6 & 54.2 & 39.8 & Post-test \\
\hline \multirow{2}{*}{$4^{*}$ PET/CT should be used as a routine imaging procedure in cancer patients. } & 68.8 & 22.0 & 9.2 & Pre-test \\
\hline & 68.3 & 26.8 & 4.9 & Post-test \\
\hline \multirow{2}{*}{$5^{\star} . \mathrm{PET} / \mathrm{CT}$ should be used as a routine imaging procedure in people free of disease. } & 28.7 & 39.8 & 31.5 & Pre-test \\
\hline & 27.5 & 40.0 & 32.5 & Post-test \\
\hline \multirow{2}{*}{$6^{\star *} . \mathrm{I}$ am worried about high-dose radiation exposure during PET/CT imaging. } & 41.8 & 41.8 & 16.4 & Pre-test \\
\hline & 39.5 & 43.2 & 17.3 & Post-test \\
\hline \multirow{2}{*}{$7^{* *}$. I will feel safe during the PET/CT scanning. } & 58.3 & 33.3 & 8.3 & Pre-test \\
\hline & 70.0 & 25.0 & 5.0 & Post-test \\
\hline \multirow{2}{*}{$8^{\star *}$. I am worried about my illness. } & 58.9 & 21.5 & 19.6 & Pre-test \\
\hline & 48,7 & 29,5 & 21,8 & Post-test \\
\hline \multirow{2}{*}{$9^{* *}$. I will feel anxious during PET/CT scanning. } & 37.4 & 21.5 & 41.1 & Pre-test \\
\hline & 28.9 & 34.2 & 36.8 & Post-test \\
\hline \multirow{2}{*}{$10^{* *}$. I fear that my PET/CT imaging report will be less than favorable. } & 50 & 15.7 & 34.3 & Pre-test \\
\hline & 50.0 & 19.2 & 30.8 & Post-test \\
\hline \multirow{2}{*}{$11^{*}$. A sufficiently high-quality PET/CT imaging will be obtained. } & 82.2 & 8.4 & 9.3 & Pre-test \\
\hline & 79.5 & 13.7 & 6.8 & Post-test \\
\hline \multirow{2}{*}{$12^{* *}$. I will feel comfortable during PET/CT scanning. } & 66.1 & 23.9 & 10.1 & Pre-test \\
\hline & 67.6 & 23.0 & 9.5 & Post-test \\
\hline \multirow{2}{*}{$13^{*}$. I have enough knowledge about PET/CT imaging. } & 48.1 & 36.1 & 15.7 & Pre-test \\
\hline & 54.2 & 36.1 & 9.7 & Post-test \\
\hline \multirow{2}{*}{$14^{*}$ I got enough answers to my questions about PET/CT imaging. } & 60.2 & 28.7 & 11.1 & Pre-test \\
\hline & 58.1 & 31.1 & 10.8 & Post-test \\
\hline \multirow{2}{*}{$15^{\star \star}$. I feel like something bad will happen to me during the PET/CT imaging. } & 12.7 & 24.5 & 62.7 & Pre-test \\
\hline & 11.8 & 27.6 & 60.5 & Post-test \\
\hline
\end{tabular}

${ }^{*}$ Questions 1, 2, 3, 4, 5, 11, 13 and 14 evaluate the knowledge and confidence related to the transaction,

${ }^{* *}$ Questions 6, 7, 8, 9, 10,12 and 15 evaluate the worry about the procedure. Questions 3, 7 and 12 were reverse scored. 


\section{DISCUSSION}

In this study, factors related to confidence and worry were evaluated in cancer patients before and after PET/CT. Anxiety is a condition caused by a person's internal conflicts and a common symptom that cancer patients often experience. Psychological reactions ranging from mild to severe have been reported previously in other publications anxiety in patients before and during invasive as well as non-invasive medical procedures. ${ }^{12-15}$ Among various scales for the clinical measurement of anxiety, we used STAI in this study.

Worry, which defines the clarified anxiety about a particular process, is a parameter independent of the anxiety of the person. However, worry and anxiety are intertwined concepts and can project with each other. In this study, we used a questionnaire which we created to measure the worry about the PET/CT procedure.

Our study consists of patients with a balanced gender distribution, having a mean age of 56 years, living mostly in the city center, and with an education level of primary school or less. In this study, no significant relationship was found between the patients' worry levels and the patients' education level, marital status, diagnosis, psychiatric treatment history and duration of illness. When the worry levels of the patients were compared with their place of residence, the worry scores of those living in rural areas were found to be higher than those living in urban areas both before and after the PET/CT procedure. It has been shown that urbanization is a risk factor for psychiatric symptoms. ${ }^{16}$

Considering the sample profiles where similar studies were conducted, although the gender distribution appeared similar to our study, some parameters (such as the educational level) were observed to differ. ${ }^{3,7,17}$

In a study, it was reported that there was no statistically significant difference between sociodemographic variables and the state anxiety levels before and after scanning. ${ }^{7}$ In our study, when looking at the relationship between gender and the total scores of the worry and confidence questions, it was found that men trusted the procedures more in the pre-test than women did. While there is no significant difference between the post-test confidence scores between men and women, it is noteworthy that women had higher worry scores in both the pre-test and the post-test. In a study, it was stated that Hospital Anxiety Depression Scale and State and Continuous Inventory I and II scores of female patients were higher, suggesting that anxiety was associated with PET/CT procedure ${ }^{17}$. Some previous studies have shown that women have higher levels of anxiety during medical procedures as well as their daily lives. ${ }^{18-20}$ In contrast to our study, some studies found that male patients undergoing PET/CT imaging for the initial or re-staging of a malignancy had higher anxiety levels and experienced more anxiety compared to women., ${ }^{3,8}$ More research is needed on this issue, since there is no consensus on the presence of any difference in anxiety between genders. ${ }^{3,21,22}$

In our study, when the total scores of the worry and confidence questions related to the PET/CT scan were compared, no significant difference was found before and after the procedure. In a study, patients' anxiety scores were found to be moderately high in both the Anxiety Depression Scale and State and Trait Inventory I and II before PET/CT imaging. ${ }^{17}$ The same study also reported that all patients had high levels of trait anxiety. This may be due to their disease-specific conditions rather than the PET/CT procedure itself. However, the increase in anxiety found in that study may be due to the PET/CT procedure, which further intensifies the basal anxiety in cancer patients. ${ }^{17}$

Similarly, in another study, it was observed that anxiety levels were higher before PET/CT imaging and significantly lower after imaging. This finding stated that cancer patients experienced anxiety during the PET/CT scan and that a significant part of the anxiety felt by the patients was 
related to the imaging process itself, possibly reflecting initial concerns about the screening procedures and the environment. $^{3}$

The perception of anxiety experienced before a medical procedure was previously evaluated in other Nuclear Medicine studies using the 10-point Likert scale ${ }^{23}$. In some other studies, ${ }^{24}$ STAI (a standard anxiety questionnaire, which is widely used in medical imaging research), was used to assess the anxiety level. Unlike those studies, and in parallel with Sun et al. ${ }^{25}$ we used both the STAI I and STAI II scales in our study.

In our study, we found a positive correlation between pre-test worry and post-test worry and STAI II. Grilo et al. found that the average anxiety levels before bone scintigraphy were higher in patients who applied to the Department of Nuclear Medicine as compared to PET/CT. They found higher mean STAI-S scores in patients after PET/CT imaging compared to bone scintigraphy and a decreased anxiety levels after imaging in both groups. They found that the most prominent factor causing anxiety in both bone scintigraphy and PET/CT scan was the imaging time. ${ }^{26}$

In a recent study using the STAI questionnaire ${ }^{25}$, Sun et al. found that patients with a confirmed diagnosis of a malignancy had higher anxiety levels than asymptomatic healthy people undergoing cancer screening. In their study, the procedure was introduced to the patients before the PET/CT scan by a video recording, and the number of patients with anxiety was found to be decreased in the patient group compared to the control group, with lower STAI-related scores.

In our study, the pre-test worries scores before PET/CT imaging of the patients who thought they had "enough knowledge about their disease" were lower and their confidence scores were higher than those who responded otherwise. At this point, no measurement was made regarding the level of knowledge about the disease. However, 48\% of our patients stated that they had enough knowledge about the procedure. In a previous study by Abreu and et al., almost $20 \%$ of patients included in their study reported not receiving any information before PET/CT and conventional Nuclear Medicine procedures. ${ }^{3}$ Nightingale and et al. mentioned that during cardiac SPECT/CT imaging, some patients in the Department of Nuclear Medicine did not fully understand the procedures and appeared confused during the explanation of such procedures. It seems that giving pre-procedure information is a necessity ${ }^{21,27}$ and having enough knowledge about the disease relates to both confidence and worry. In a study by Lledo and et al., when patients were informed before a medical procedure, their anxiety levels decreased and this significantly increased their satisfaction perceptions. ${ }^{23}$

On the other hand, although a study conducted by Domenech and et al. ${ }^{28}$ stated that the amount of information given before a procedure in a Nuclear Medicine Department did not affect the presence of anxiety in patients, our results showed that having enough knowledge affects the perception of worry in patients.

In this study, the majority of our patients relied on the treatment team, based on their positive responses to the question "PET/CT imaging is ordered by the doctor because it is really necessary" both before $(87 \%)$ and after (91\%) PET/CT imaging. However, only $50 \%$ of these patients believed that "the benefit from PET/CT scan exceeded the radiation risk they were exposed to", with the positive response rate decreasing to $42 \%$ after imaging. The ratio of those who 'disagreed' with the statement "PET/ CT scan increases my risk of getting cancer" remained at $41 \%$. This suggests that there is a difference between feeling knowledgeable and the quality of information (namely, having the correct knowledge). Although our patients generally express confidence about the procedures, the ratio of those who responded to having received enough information was approximately half (pre-test $48 \%$ versus 
post-test 54\%) and the ratio of those who stated that they got enough answers to their questions remained around $60 \%$. When considering all questions, it is obvious that the content of misinformation continues. As mentioned before, although Domenech et al. ${ }^{28}$ stated that the amount of information given before a procedure to be performed in a Nuclear Medicine Department does not affect the presence of anxiety in the patient, findings in our study remind us that confidence has a dimension other than mere knowledge. Although it can be argued that confidence is based on a healthy patient-physician relationship considering the cultural composition of our society, this interpretation requires additional research.

An important finding in this study is that when patients were adequately informed about their illnesses, it helped to increase confidence in the procedures performed and decreased anxiety levels of the patients during the procedure. A positive relationship that physicians will establish with their patients and a detailed information to be given to the patients will help patients feel safer at the point of further procedures. The follow-up of cancer patients is not only carried out by the oncology team. In fact, the follow-up process is multidisciplinary in nature. When physicians provide information of their own, this results in a reassuring attitude with the patient and contributes to making other procedures in the treatment process more reliable.

In a study in which the majority (almost two-thirds) of patients who underwent PET/CT imaging for the first time for the initial staging of an oncological disorder, it was reported that the reason for the high anxiety levels before imaging could relate to the fear of unknowns about the effects of the procedure and radiation. ${ }^{3}$ Another similar study found that the most common cause of anxiety was the worry about the results of the imaging procedures. ${ }^{29}$

When the concerns of the patients about exposure to highdose radiation during PET/CT imaging were questioned, it was observed that the percentages of those who said "I agree" before and after imaging were close to each other
( $42 \%$ and $40 \%$, respectively). On the other hand, most of the patients (69\%) stated that "PET/CT imaging should be used as a routine screening method in patients with cancer". Hereby, the rate of those (40\%) who were undecided about "of PET/CT being a routine imaging procedure in patients without cancer" was higher compared to those who agreed or disagreed.

This study has some limitations, one of which is the sample size. The avoidant attitude of the patients participating in the study in filling out all forms constituted a limitation in reaching the desired sample size and subsequently interpreting the data. Another limitation is that "patients feel informed about themselves", but no evaluation has been made about the true level of knowledge of the patients. However, there are only a few studies evaluating cancer patients before and after PET/CT imaging and this study can be regarded to have a high-quality based on its multidisciplinary context.

\section{CONCLUSION}

When working with cancer patients, Nuclear Medicine physicians must be aware of their patients' mood and be prepared to deal with potential anxiety. Providing information about the disease and the procedure to be performed seems to be beneficial in helping patients feel safer and reducing their level of worry. However, the content and quality of the information does not appear as an indicator of confidence and worry. Further research is needed on what makes patients feel safe and how to provide them with the feeling of safety.

\section{Ethical approval}

Ethics committee approval was given for this study from the Sakarya University Faculty of Medicine Ethics Committee on 11 October 2017 (Ethics no: $16214662 / 050.01 .04 / 68)$

\section{Conflict of Interest}

There is no conflict of interest to declare for this paper 
Sakarya Med J 2021;11(4):879-888

ILÇE et al., : Oncologıcal Patıents' Opınıons Before And After Pet/Ct Scans

\section{References}

1. Kitajima K, Doi H, Kanda T, et al. Present and future roles of FDG-PET/CT imaging in the management of lung cancer. Japanese journal of radiology. Jun 2016;34(6):387-399.

2. Grilo A, Vieira L, Carolino E, et al. Anxiety in cancer patients during 18F-FDG PET/CT low dose: a comparison of anxiety levels before and after imaging studies. Nursing research and practice. 2017;2017.

3. Abreu C, Grilo A, Lucena F, Carolino E. Oncological Patient Anxiety in Imaging Studies: the PET/CT Example. Journal of cancer education : the official journal of the American Association for Cancer Education. Dec 2017;32(4):820-826.

4. Dean E. Anxiety. Nursing standard. Jul 13 2016;30(46):15.

5. Schuyler D. Anxiety. The primary care companion for CNS disorders. Oct 13 2016;18(5).

6. Turkcapar H. Bilișsel Davranışçı Terapi-Temel İlkeler ve Uygulama Epsilon Yayınevi; 2018.

7. Grilo A, Vieira L, Carolino E, et al. Anxiety in Cancer Patients during (18)F-FDG PET/ CT Low Dose: A Comparison of Anxiety Levels before and after Imaging Studies. Nursing research and practice. 2017;2017:3057495.

8. Pifarre P, Simo M, Gispert JD, Pallares MD, Plaza P, Martinez-Miralles E. [Diagnostic imaging studies: do they create anxiety?]. Revista espanola de medicina nuclear. Nov-Dec 2011;30(6):346-350.

9. Liu Y. Fluorodeoxyglucose uptake in absence of CT abnormality on PET-CT: What is it? World journal of radiology. Dec 28 2013;5(12):460-467.

10. Spielberger CD GR, Lushene RE. Test manual for the State Trait Anxiety Inventory. 1 st ed. ed. California: Consulting Psychologists Press; 1970.

11. Öner N LCA. Süreksiz durumluk /sürekli kaygı envanteri el kitabl. 1. Baskı ed. İstanbul Boğaziçi Üniversitesi Yayını; 1983

12. McIsaac HK, Thordarson DS, Shafran R, Rachman S, Poole G. Claustrophobia and the magnetic resonance imaging procedure. Journal of behavioral medicine. Jun 1998;21(3):255-268.

13. Frenzer A, Binek J, Hammer B. [Physician-patient relations and stress caused by coloscopy in patients with chronic inflammatory bowel disease]. Schweizerische medizinische Wochenschrift. Supplementum. 1996;79:94S-96S

14. Kutluturkan S, Gorgulu U, Fesci H, Karavelioglu A. The effects of providing pre-gastrointestinal endoscopy written educational material on patients' anxiety: a randomised controlled trial. International journal of nursing studies. Sep 2010;47(9):1066-1073.

15. Carneiro AF, Mathias LA, Rassi Junior A, Morais NS, Gozzani JL, Miranda AP. [Evaluation of preoperative anxiety and depression in patients undergoing invasive cardiac procedures]. Revista brasileira de anestesiologia. Jul-Aug 2009;59(4):431-438.

16. Thomas $F$. The role of natural environments within women's everyday health and wellbeing in Copenhagen, Denmark. Health \& place. Sep 2015;35:187-195.

17. Elboga U EG, Can C, Sahin E, Karaoglan H, Kalender E, et al. . Assessment of procedure related anxiety and depression in oncologic patients before F-18 FDG PET-CT imaging. J Psychiatry. 2015(18):2013-2016.
18. Zender R, Olshansky E. Women's mental health: depression and anxiety. The Nursing clinics of North America. Sep 2009;44(3):355-364.

19. Luck A, Pearson S, Maddern G, Hewett P. Effects of video information on precolonoscopy anxiety and knowledge: a randomised trial. Lancet. Dec 11 1999;354(9195):2032-2035.

20. Dantendorfer K, Amering M, Bankier A, et al. A study of the effects of patient anxiety, perceptions and equipment on motion artifacts in magnetic resonance imaging. Magnetic resonance imaging. 1997;15(3):301-306.

21. Nightingale JM, Murphy FJ, Blakeley C. 'I thought it was just an x-ray': a qualitative investigation of patient experiences in cardiac SPECT-CT imaging. Nuclear medicine communications. Mar 2012;33(3):246-254.

22. Tornqvist E, Mansson A, Larsson EM, Hallstrom I. Impact of extended written information on patient anxiety and image motion artifacts during magnetic resonance imaging. Acta radiologica. Jun 2006;47(5):474-480.

23. Lledo R, Herver P, Garcia A, Guell J, Setoain J, Asenjo MA. Information as a fundamental attribute among outpatients attending the nuclear medicine service of a university hospital. Nuclear medicine communications. Feb 1995;16(2):76-83.

24. Vogel WV, Valdes Olmos RA, Tijs TJ, Gillies MF, van Elswijk G, Vogt J. Intervention to lower anxiety of 18F-FDG PET/CT patients by use of audiovisual imagery during the uptake phase before imaging. Journal of nuclear medicine technology. Jun 2012;40(2):92-98.

25. Sun Y, Sun Y, Qin Y, Zhang Y, Yuan H, Yang Z. 'Virtual experience'as an intervention before a positron emission tomography/CT scan may ease patients' anxiety and improve image quality. Journal of Medical Imaging and Radiation Oncology. 2020;64(5):641-648.

26. Grilo AM, Vieira L, Carolino E, et al. Cancer Patient Experience in a Nuclear Medicine Department: Comparison between Bone Scintigraphy and 18F-FDG PET/CT. Journal of nuclear medicine technology. 2020:jnmt. 119.239285.

27. Groves AM, Kayani I, Syed R, Gacinovic S, Nagabushan N, Ell PJ. Myocardial perfusion scintigraphy: patients' perception of benefit and risk. Nuclear medicine communications. Dec 2004;25(12):1219-1222.

28. Domenech A, Notta P, Benitez A, et al. [Evaluation of the anxiety state in patients receiving radioiodine treatment or who undergo a sentinel lymph node examination in the Nuclear Medicine Department]. Revista espanola de medicina nuclear. Mar-Apr 2010;29(2):63-72.

29. Ollivier L, Apiou F, Leclere J, et al. Patient experiences and preferences: development of practice guidelines in a cancer imaging department. Cancer imaging : the official publication of the International Cancer Imaging Society. Oct 2 2009;9 Spec No A:S92-97. 